This is a self-archived version of an original article. This version may differ from the original in pagination and typographic details.

Author(s): Suuronen, Ville

Title: Biologisoituva politiikka vai politisoituva biologia? : biopolitiikan arvoituksesta

Year: 2017

Version: Published version

Copyright: (c) 2017 Ville Suuronen

Rights: In Copyright

Rights url: http://rightsstatements.org/page/lnc/1.0/?language=en

Please cite the original version:

Suuronen, V. (2017). Biologisoituva politiikka vai politisoituva biologia? : biopolitiikan arvoituksesta. Tiede ja edistys, 42(3), 269-272. https://doi.org/10.51809/te.105266 


\section{BIOLOGISOITUVA POLITIIKKA VAI POLITISOITUVA BIOLOGIA? BIOPOLITIIKAN ARVOITUKSESTA}

Ilpo Helén: Elämän Politiikat.

Yhteiskuntatutkimus Foucault'n jälkeen. Tutkijaliitto 2016.

ELÄMÄN POLITIIKKA TUTKIMUSKOHTEENA

Mitä on biopolitiikka? Ilpo Helén antaa tuoreessa teoksessaan Elämän Politiikat: Yhteiskuntatutkimus Foucault n jälkeen biopolitiikalle osuvan määritelmän kirjoittaessaan, että"politiikka on biopolitiikkaa, kun sen kiintopiste on elämä biologisena asiana, olemassaolon kysymyksenä tai elämäntavaksi, elämänkerraksi tai elämänhallinnaksi ymmärrettynä” (2016,219). Biopolitiikalla - suomeksi elämän politiikalla - ei ole mitään yksiselitteistä objektia, vaan se kohdistuu pikemminkin "elämänilmiöihin niiden runsaudessa ja moninaisuudessa" (Helén 2016, 42). Tämä määritelmä heijastaa osuvasti sitä tosiasiaa, että viime vuosikymmenien aikana biopolitiikan tutkimus on muodostunut ja vakiintunut monialaiseksi tutkimuksen kentäksi. Tutkimuksen kirjo on laaja ja myös ambivalentti; teemat liikkuvat ja risteävät esimerkiksi politiikan tutkimuksen, historian, lääketieteen, filosofian, geeniteknologioiden, sukupuolentutkimuksen, turvallisuutta koskevien aiheiden ja taloustieteen alueilla ja välimaastossa (yleisesityksiä aiheesta ks. Lemke 2011; Prozorov ja Rentea 2017).

Vaikka biopolitiikan käsitteen juuret voidaan paikantaa 1900-luvun alkupuolella vaikuttaneen ruotsalaisen geopolitiikan tutkijan Rudolf Kjéllenin (1864-1922) työhön
(Lemke 2011, 9-13; Helén 2016 10-11), on ranskalaisfilosofi Michel Foucault'n (19261984) laajasti luetuilla tutkimuksilla ollut yhteiskuntakriittisen biopolitiikan tutkimuksen kehityksen kannalta erityinen merkitys, sillä juuri Foucault'n ajattelu on monien tunnetuimpien biopolitiikan tutkijoiden työn taustalla. Foucault määrittää Seksuaalisuuden Historian ensimmäisessä osassa biologisen elämän ja poliittisen hallinnan yhteen kietoutumisen - "biologisen moderniuden kynnyksen" - kuuluisin sanoin:

\begin{abstract}
Vuosituhansien ajan ihminen oli sellainen kuin hän oli Aristoteleelle: elävä eläin, jolla on lisäksi poliittisen olemassaolon kyky. Moderni ihminen on eläin, jonka elämän hänen politiikkansa elävänä oliona asettaa kyseenalaiseksi. (Foucault 2013, 105.)
\end{abstract}

Foucault'n mukaan biopolitiikassa on siis kyse tunnusomaisesti modernista ilmiöstä: juuri modernin valtion kontekstissa elämästä biologisessa mielessä tulee poliittisen hallinnan kohde. Mainitun Tiedontabdon (1976) lisäksi Foucault tutki biopolitiikkaa erityisesti kolmella Collège de Francen luentosarjallaan. Vuoden 1975-1976 luennot (Il faut défendre la société) käsittelivät erityisesti biovallan ja kurivallan suhdetta historiallisesta näkökulmasta ja rasismin moniulotteista historiaa sekä sen huipentumista 1900-luvun totalitaarisissa valtioissa. Sapattivuoden jälkeen pidetyllä vuosien 1977-1978 luentosarjallaan Sécurité, territoire, population (suom. Turvallisuus, alue, väestö) Foucault jäljitti biovallan alkuperää 
hallinnallisuuden tapana tutkimalla varhaisissa kristillisissä yhteisöissä kehittynyttä ideaa laumaansa hoitavasta sielunpaimenesta. Foucault esitti, että modernien valtioiden biopoliittisen hallinnallisuuden erityispiirre on nimenomaan kokonaisten väestöjen muotoutuminen hallinnan, tuotannon, hoitamisen, verotuksen ja lääkinnän kohteiksi. Vuosien 1978-1979 luentosarjan (La naissance de la biopolitique) oli taas tarkoitus käsitellä eksplisiittisesti myöhäismodernin biovallan suhdetta liberalismin syntyhistoriaan ja ideamaailmaan, mutta tämän yhteyden tutkiminen jäi puolitiehen. Sen sijaan Foucault tarjoaa näillä luennoillaan kriittisen analyysin 1900-luvun poliittisesta ympäristöstä tutkimalla uusliberalismia.

Ilpo Helénin uusin teos lähtee liikkeelle juuri näistä Foucault'n biopolitiikkaa käsittelevistä tutkimuksista ja tarjoaa suomenkieliselle lukijalle perinpohjaisen johdatuksen biopolitiikan tutkimuksen laajaan kirjoon. Kirjan tavoitteena on pohtia Foucault'n ajattelun ja genealogisen metodin ajankohtaisuutta kriittisinä välineinä sekä hahmotella biopolitiikan tutkimuksen linjoja Foucault'n jälkeen. Erityisesti Helén argumentoi, että biopolitiikka tulisi ymmärtää elämää luovasti affirmoivana toimintana; elämän politiikan ytimessä ei ole niinkään ihminen ja hänen biologiansa sinänsä, vaan ihmisen potentiaalisuus elävänä olentona. Juuri modernin teknologian kehitys - esimerkiksi biolääketieteen ja geeniteknologioiden muodossa - osoittaa, että elämän politiikan ytimessä on enenevissä määrin olemisen potentiaalisuus.

BIOPOLITIIKAN HISTORIA

JA NYKYISET SFÄÄRIT

Teos alkaa Foucault'n metodologian ja tutkimusten analyysilla. Viitaten Foucault'n kuuluisaan ideaan "oman itsemme ontologiasta" (ks. esim. Foucault 2007) Helén pyrkii esittämään ja avaamaan elämän politiikan kehityslinjat sekä elämän politiikkaa käsittelevän tutkimuskentän tavalla, joka mahdollistaa oman aikamme kriittisen ymmärtämisen (Helén 2016, 15-33). Kantin tapaan Foucault tutkii ajattelun ja ymmärryksen ehtoja, mutta toisin kuin kantilainen transsendentaalifilosofia, joka etsii ymmärryksen ja ajattelun universaaleja ja muuttumattomia ehtoja, Foucault'n genealogia ymmärtää universaalit kontingentteina ja historiallisina muodostelmina, joiden juuret voidaan palauttaa subjektivoiviin vallan $\mathrm{ja}$ tiedon suhteisiin ja verkostoihin (ks. aiheesta Koivusalo 2012).

Biopolitiikan kehittymisen kannalta keskeisessä osassa on historiallinen kehityskulku, jonka myötä elämä muuttuu tieteellisen tutkimuksen ja teknologian kohteeksi, ja toisaalta poliittinen muutos feodaaliyhteiskunnista suvereenin vallan määrittämiin valtioihin. Elämästä muodostuu asteittain tieteellinen tutkimuskohde 1700-luvun lopulta alkaen. Biologian, kliinisen ja kokeellisen lääketieteen sekä empiiristen ihmistieteiden - kuten psykologian ja sosiaalitutkimuksen - kehityksen myötä ihmisestä biologisena ja elävänä olentona tulee tieteellisen tutkimuksen kohde. Nämä episteemiset murrokset ovat biopolitiikan synnyn kannalta avainasemassa: 1900-luvulle tultaessa jokapäiväisestä inhimillisestä elämästä on muodostunut taloudellisen hallinnan kohde ja teknologian objekti. (Helén 2016, 45-6.)

Modernin valtion ja väestön ideat taas kiteytyvät 1500-luvun lopun ja 1700-luvun alun välisenä aikana, etenkin Ludvig XIV:n Ranskassa, Kustaa Vaasan Ruotsissa ja Preussissa. Tämä poliittinen kehityskulku heijastuu esimerkiksi Jean Bodinin, Thomas Hobbesin, Francisco Suárezin ja Olaus Petrin valtiota ja suvereniteettia koskevissa teorioissa. Politiikan valtiollistumista ja valtion vahvistamiseen keskittynyttä poliisitiedettä (Polizeiwissenschaft) seuraa läheisesti hallinnan taloudellistuminen Adam Smithin, David Ricardon ja ranskalaisten fysiokraattien talousteorioissa sekä marxilaisessa taloustieteen kritiikissä. Taloudellistumista taas seuraa poliittisen liberalismin ja malthusilaisen väestötieteen nousu. Foucault'n mukaan modernin hallinnallisuu- 
den eetoksen - jonka piiriin kuuluvat esimerkiksi köyhyyttä, terveyttä ja terveydenhuoltoa, rikollisuutta ja koulutusta koskevat väestö- ja tilastotieteelliset ongelmat - juuret voidaan paikantaa juuri liberalismin syntyhistoriaan. Väestövaltion syntyä 1700-luvulla seuraa siis sosiaalivaltion kehitys 1800- ja 1900-luvuilla. 1900- ja 2000-lukujen politiikkaa taas määrittelee markkinahallinnan voittokulku. (Helén 2016, 64, 129-31, 136-7, 140, 280.)

Helén $(2016,177-8,216)$ argumentoi, että viime vuosikymmenien poliittisen kehityksen myötä valtio on muuttumassa vain yhdeksi markkinahallinnan osapuoleksi yritysten ja kolmannen sektorin välillä. Biopoliittisen hallinnan hajaantumista vastaa uudenlaisen subjektiviteetin tuottaminen: kun ihmisyys muuttuu kaikilla elämänalueilla markkinahallinnan määrittämäksi, tulee ihmisistä itsestään oman elämänsä yrittäjiä; biopoliittisesta hallinnasta tulee siis myös itsetekniikka. Paul Rabinowin ja Nikolas Rosen tutkimuksia mukaillen Helén esittää, että 21. vuosisadan biopolitiikka sijoittuu yhä vahvemmin molekyylitasolle: biologisen muokattavuuden horisontti avautuu kaikkein selkeimmin biolääketieteen ja terveydenhoidon areenoilla (Helén 2016, 83-4, 222-37, 274). Molekulaarista politiikkaa määrittää kokeellisuus, jonka myötä itse ihmiselämä - Martin Heideggerin (1953) kuuluisaa ilmaisua lainaten - näyttäytyy pelkkänä muokattavuuden, kokeilun ja materiaalin "varantona" (Gestell).

Vaikka teos kiinnittyykin vahvasti Foucault'n ajattelun avaamille poluille, teoksen ytimessä on myös yritys avata Foucault'n ajattelun umpikujia. Kuten Helén $(2016,10)$ huomauttaa, Foucault'n genealogisesta metodista ja hallinnan analytiikasta on muodostunut jossain määrin 1970-luvun marxismiin verrattavaa valtavirtaa, josta puuttuu tuoreen ajattelutavan lumo. Teos päättyykin kriittiseen ja provokatiiviseen alluusioon sekä Foucault'n että Marxin ideoihin ja hahmottelee heidän ajatuksiaan yhdistävän yhteiskuntakritiikin suuntaviivoja:
Jos Marxin proletaarilla ei ollut muuta myytävää kuin työvoimansa, nykyköyhällä ei ole panna maailmantalouden peliin muuta kuin elinvoimansa joko lääketieteellisen kokeen alustana, biomateriaalin ja -informaation luovuttajana, elinluovuttajana tai sijaiskohtuna (Helén 2016, 371).

Nämä loppusanat tuovat mieleen Kazuo Ishiguron dystopiaromaanin Ole luonani aina (2005), jonka fiktiivisessä maailmassa väestö on jaettu biologisena varantona toimiviin klooneihin ja heitä hyödyntäviin ihmisiin. Foucault'n ja Marxin yhteiskuntafilosofioiden rajat tulevat esiin juuri tässä: pysäyttämätön teknologinen ja taloudellinen kehitys - esimerkiksi geeniteknologian tai perustulon muodossa - pakottaa meidät etsimään kriittistä horisonttia, joka mahdollistaa perustavien eettisten ja poliittisten kysymysten uuden muotoilemisen.

\section{LOPUKSI}

Elämän politiikat on asiantunteva ja kattava tutkimus biopolitiikan historiasta sekä nykyisen tutkimuksen polttopisteistä. Teosta kuitenkin rasittaa sen pituus ja toisteisuus. Esimerkiksi ensimmäisen luvun metodologisiin pohdintoihin palataan uudestaan kahdeksannessa luvussa; biopolitiikan kehitystä ja muutosta käsittelevät keskeiset historialliset kehityslinjat toistetaan lukemattomia kertoja, kuten myös biososiaalisuutta ja biologista kansalaisuutta koskevat keskeiset pohdinnat.

Helén täydentää laajoja historiallisia kehityslinjoja koskevia esityksiään yksittäisiin aiheisiin keskittyneillä ekskursioilla, jotka on sijoitettu leipätekstin väliin erillisiksi osioiksi. Nämä osiot tutkivat esimerkiksi PohjoisKarjala-projektia, addiktioiden historiaa, sosiaalivaltioiden hallinnallisen politiikan eri puolia, seksuaalisuutta ja Hi-virusta politiikan kohteena. Monet Helénin tarjoamat ekskursiot ovat turhan vahvasti kiinnittyneitä poh- 
joismaiseen ja etenkin Suomen historiaan, kun taas esimerkiksi totalitarismia - joka on usein nähty biopolitiikan historian brutaalina huipentumana - käsitellään vain ohimennen.

Lisäksi teos kärsii jossain määrin selektiivisyydestä tutkimuskirjallisuuden suhteen (vrt. esim. biopolitiikan antologia, Campbell ja Sitze 2013). Vaikka Helénin esitys onkin erittäin kattava, esimerkiksi Roberto Espositon (2008) sekä Michael Hardtin ja Antonio Negrin (2000) tunnettuja teoksia ei käsitellä ollenkaan. Suhteellisen vähäiselle huomiolle jäävät myös esimerkiksi Giorgio Agambenin (1995; 2003) biopolitiikkaa käsittelevät tutkimukset sekä Hannah Arendtin klassikkoteokset The Origins of Totalitarianism (1951) ja The Human Condition (1958), joista voidaan löytää Foucault'n tutkimuksia varhaisempi biopolitiikan analyysi (vrt. Helén 2016, 60-2, 367-70).

Myös Helénin päätös ahtaa jokaisen luvun taustalla oleva keskeinen tutkimuskirjallisuus

\section{KIRJALLISUUS}

Agamben, Giorgio (1995/1998) Homo Sacer: Sovereign Power and Bare Life. Käänt. Daniel Heller-Roazen. Stanford, Stanford University Press.

Agamben, Giorgio (2003/2005) State of Exception. Käänt. Kevin Attell. Chicago, University of Chicago Press.

Arendt, Hannah (1951/1994) The Origins of Totalitarianism. New York, Harcourt.

Arendt, Hannah (1958/1989) The Human Condition. Chicago, Chicago University Press.

Campbell,Timohty \& Sitze, Adam (toim.) (2013) Biopolitics: A Reader. Durham, Duke University Press.

Esposito, Roberto (2008) Bíos: Biopolitics and Philosophy. London, University of Minnesota Press.

Foucault,Michel (2003) "Society must be Defended". Lectures at the Collège de France 1975-1976. New York, Picador.

Foucault, Michel (2007) "Kant ja moderni filosofia nykyisyyden ontologiana”. Suom. Juha Koivisto ja Tarmo Malmberg. Teoksessa Koivisto et al. (toim.) Mitä on valistus? Tampere, Vastapaino, 241-252.

Foucault, Michel (2008) The Birth of Biopolitics. Lectures at the Collège de France 1978-1979. New York, Picador.

Foucault, Michel (2009) Security, Territory, Population. lukujen alussa sijaitseviin alaviitteisiin on ongelmallinen. Vaikka yhtäältä kyseinen lähestymistapa tekeekin Helénin kirjoitustyylistä esseistisen ja helposti lähestyttävän, toisaalta se myös usein johtaa tutkimuksellisen otteen heikkenemiseen ja tarpeettoman pitkiin kirjallisuusluetteloihin.

Tästä kaikesta huolimatta Helénin teos muodostaa hyvän ja toimivan kokonaisuuden: se on erinomainen johdatus biopolitiikan tutkimukseen perehtymättömälle lukijalle, ja laajuutensa vuoksi teos toimii myös syventävänä lukemisena aiheeseen jo perehtyneelle. Helénin keskeinen teesi biopoliittisen hallinnan luonteen muutoksesta ja tulevaisuuden biopolitiikan keskittymisestä inhimillisen potentiaalisuuden muokkaamiseen on vakuuttava ja kattavasti perusteltu.

\section{- VILLE SUURONEN}

Lectures at the Collège de France 1977-1978. New York, Picador. Suomennos Turvallisuus, alue, väestö. . Suom. Antti Paakkari. Helsinki, Tutkijaliitto, 2010.

Foucault, Michel (2013) Tiedontahto. Seksuaalisuuden historia, osa I. Suom. Kaisa Sivenius. Helsinki, Gaudeamus.

Hardt, Michael \& Negri, Antonio (2000/2005) Imperiumi. Suom. Arto Häilä et al. Helsinki, WSOY.

Heidegger, Martin (1953) "Die Frage nach der Technik". Teoksessa Martin Heidegger (toim. F.-W. von Herrmann), Vorträge und Aufsätze. Frankfurt am Main, Klostermann, 5-36.

Helén, Ilpo (2016) Elämän politiikat: Yhteiskuntatutkimus Foucault'n jälkeen. Helsinki, Tutkijaliitto.

Ishiguro, Kazuo (2005) Ole luonani aina. Suom. Helene Bützow. Helsinki, Tammi.

Koivusalo, Markku (2012) Kokemuksen politiikka. Michel Foucault'n ajattelujärjestelmä. Helsinki, Tutkijaliitto.

Lemke, Thomas (2011) Biopolitics: An Advanced Introduction. Käänt. Eric Frederick Trump. New York, New York University Press.

Prozorov, Sergei \& Rentea, Simona (toim.) (2017) The Routledge Handbook of Biopolitics. London, Routledge. 